ConNotas. Revista de crítica y teoría literarias / Vol. VI, Núm. 10 / 2008

\title{
Simbolismo y Modernismo
}

\author{
LUIS BELTRÁN*
}

\section{Resumen:}

El artículo cuestiona la dicotomía realismo/modernidad. Los estudios literarios occidentales del siglo pasado trataron de entender las diferencias estéticas entre el siglo XIX y el XX basándose principalmente en un concepto de mimesis. Estos intentos por explicar dichas diferencias están basados en una serie de reacciones ante los eventos artísticos mayores de la época; sin embargo, estas reacciones fueron de muy poco alcance como para definir a posteriori unas diferencias múltiples y proteiformes. Por lo anterior, el autor sugiere una concepción más amplia tomando en cuenta factores de mayor significación. De esta manera, el simbolismo, catalogado por la crítica como una moda creativa del último tercio del siglo XIX y asociado por algunos críticos al romanticismo y por otros a manifestaciones artísticas del siglo XX, es en realidad un fenómeno que se percibe desde Rabelais hasta Soldados de Salamina. El simbolismo se caracteriza como una estética marcada por el hermetismo y la comicidad; una vuelta a la oralidad aunque distinta de la primitiva.

\section{Palabras clave:}

Realismo, modernidad, simbolismo, mimesis, Javier Cercas, Soldados de Salamina, crítica literaria, historia literaria, periodización. 


\section{Realismo y modernismo}

Desde hace aproximadamente un siglo viene dándose, primero en Europa y después en Estados Unidos un debate sobre el realismo y la estética dominante en el siglo XX. Quizá sería más claro si dijera que ese debate viene a negar que el realismo sea la estética dominante del siglo XX, incluso la estética moderna, como habían creído pensadores y críticos en el s. XIX y en la primera mitad del s. XX. Hoy existe cierto consenso, un consenso que abarca desde la crítica anglosajona a la rusa, pasando por otros ámbitos europeos, en que el s. XX es el siglo del modernismo, como el siglo XIX lo fue del realismo. En lo que no hay tal consenso es en qué debemos entender por modernismo y por realismo. Conviene aclarar que el concepto de modernismo que se maneja en los estudios literarios norteamericanos y europeos no es el que manejamos los hispanos de ambas orillas del Atlántico (es decir, de Rubén Darío y sus seguidores), sino mucho más amplio. The Johns Hopkins Guide to Literary Theory \& Criticism define modernismo como un movimiento internacional que rompe las ortodoxias establecidas, celebra el presente y anima a la investigación experimental del futuro.

Pero volvamos al tema del consenso. En realidad, este es el mecanismo habitual de los estudios literarios y de otras disciplinas, el establecimiento de consensos superficiales (términos sin concepto, rutinas metodológicas, etc.) que ayudan a mantener la apariencia de un estado de cosas respetable e, incluso, inamovible. Pero no es el funcionamiento de los estudios literarios el tema que nos interesa ahora, sino el debate entre realismo y modernismo. Voy a intentar un sucinto bosquejo de esta cuestión con la esperanza de arrojar alguna luz sobre este espinoso y polémico asunto. Intentaré mostrar que ésta es una cuestión relevante que no se limita a un problema de mera terminología, sino que afecta a la forma de pensar la literatura moderna.

Como decía, el siglo XX ha observado con desconfianza la noción de realismo. El pensador español José Ortega y Gasset fue uno de los primeros en afirmar la inadecuación de la noción de realismo para el arte moderno. Veía en 1912 el florecimiento de una estética 
nueva, más poética y trascendente que la realista. Después vinieron otros. Unos afirmando la disparidad entre el arte del siglo XIX y el arte del siglo XX. Otros dudando de la eficiencia y veracidad de la noción de realismo (Jakobson afirmó que el realismo era el producto de un doble equívoco). Incluso quienes, como Auerbach, hicieron del realismo una cuestión central de su pensamiento vieron la necesidad de deslindar el realismo del siglo XIX del arte del siglo XX que dieron en llamar modernismo. En Rusia esta misma idea está presente en la obra de Eleazar Meletinski. Los más se han dedicado a dudar de la eficiencia de la caracterización realista aun sin cuestionarla abiertamente, añadiéndole otros contenidos que desdibujaban esa primera noción. Conceptos como realismo mágico o realismo figural ilustran esta actitud.

Ortega vio en el realismo su vis comica. "El germen del realismo se halla en un cierto impulso que lleva al hombre a imitar lo característico de sus semejantes o animales [...] El que imita, imita para burlarse. Aquí tenemos el origen que buscamos: el mimo" (221). Y concluye: "El siglo XIX -siglo burgués, democrático y positivistase ha inclinado en exceso a ver la comedia sobre la tierra" (221). Esta asociación orteguiana entre realismo y comedia le lleva a dar un diagnóstico acerca de la novela que nos puede ser útil para comprender la dinámica del arte del siglo XX: "Si la novela contemporánea pone menos al descubierto su mecanismo cómico, débese a que los ideales por ella atacados apenas se distancian de la realidad con que se los combate. La tirantez es muy débil: el ideal cae desde poquísima altura. Por esta razón puede augurarse que la novela del siglo XIX será ilegible muy pronto [escribe esto en 1912]: contiene la menor cantidad de dinamismo poético" (233). Y termina recordando que dos tontos, Bouvard y Pécuchet, enterraron la poesía -en honor a la verosimilitud y al determinismo- una noche en el Père Lachaise (235).

Esta idea, la de una confrontación estética entre los siglos XIX y $\mathrm{XX}$, ha hecho fortuna. Con mayor o menor clarividencia, han sido muchos los que han venido alimentándola. Un punto de vista original en el panorama de la crítica se lo debemos a Erich Auerbach y fue expuesto en Mimesis. Auerbach dedicó su monumental obra a 
explicar que el gran logro de la cultura occidental consiste en identificar realidad con historia (White, 315). El gran proyecto estético de Auerbach desemboca en una conclusión no exenta de paradoja: la posibilidad de una realización conjunta del realismo y del modernismo. Esto significa que el modernismo no es una huida de la historia sino la consumación del realismo, al trascender el realismo del siglo XIX. El modernismo, según Auerbach, se guía por el mismo criterio del realismo; esto es, ver el presente como historia. Pero lo hace con una nueva fórmula: la fusión de la historia y la ficción.

El pensador ruso Eleazar Meletinski ofrece un punto de vista también sugerente y discutible apelando a "principios psicológicos y metafísicos universalmente humanos." Para este teórico ruso el modernismo ha supuesto la ambición por superar los límites histórico-sociales y espacio-temporales gracias a la revelación de ese contenido universal. Ahí ve la clave del paso del realismo del siglo XIX al modernismo actual. Para ese paso resulta esencial la recuperación del lenguaje arcaico del simbolismo mitológico y su "psicología de lo profundo, que pervive en los modelos eternos del comportamiento individual o social, así como las leyes fundamentales del cosmos" (7).

La tendencia actual ha cristalizado estas propuestas y supone que el modernismo es una actitud desarrollada por el siglo XX frente al s. XIX. Esta posición suele fijarse en aspectos tales como la presencia de la función mítica o epifanía, la incertidumbre epistemológica y la autorreflexión metalingüística y metaficcional, rasgos que algunos han transferido al posmodernismo (Ródenas, 71). La idea de la función mítica como frontera modernista proviene de la autoridad que emanan Joyce y T. S. Eliot. En efecto, ambos autores popularizaron el fenómeno de la epifanía, pero este fenómeno está también presente en la literatura del s. XIX y no sólo en la vertiente fantástica de la producción de ese siglo. Los otros dos aspectos -epistemológico y metaficcional- aluden a la deriva del individualismo -esto es, de la forma que adopta el pensamiento moderno- que ha pasado de la posición fuerte del s. XIX -el individualismo crítico, que se cree en posesión de la verdad-a 
posiciones débiles en el siglo $\mathrm{XX}$-el individualismo relativista $\mathrm{y}$ el escéptico. ${ }^{1}$

En los estudios literarios anglosajones e hispánicos de la década de los 90 este debate ha dado un último giro, por el momento: algunos ven en el modernismo las huellas del escepticismo. Ese escepticismo constituiría una nueva posición del espíritu moderno frente al autoritarismo del siglo XIX (lo que algunos pensadores llamaron individualismo crítico, diferenciándolo del relativismo y del escepticismo). En una reciente conferencia Fredric Jameson ha ido un paso más allá al proponer el concepto de realismo providencial, una nueva categoría con la que se propone enriquecer y ampliar nuestra concepción del gran realismo y sus posibilidades. Esta aportación resulta interesante por abrir una nueva vía a partir de lo que Jameson llama "novela providencial", que ilustra con Middlemarch (George Eliot). Pero lo que ahora nos interesa es la actitud de Jameson. El teórico norteamericano no cuestiona los conceptos de realismo y modernismo. Simplemente los enriquece con una clasificación binaria. A partir de los conceptos de inmanencia y trascendencia, define cuatro categorías: el gran realismo (la inmanencia inmanente), su desviación ética (la inmanencia trascendente), su desviación política (la trascendencia trascendente) y lo providencial (trascendencia inmanente), producto de la articulación de providencia y destino. A este asunto del realismo providencial vamos a dedicar esta intervención, intentando si fuera posible ir un poco más allá de este galimatías conceptual.

${ }^{1}$ En las últimas décadas del s. Xx el escepticismo ha tomado al asalto las disciplinas humanísticas -la revuelta foucaultiana es su expresión más visible-. Los profetas del escepticismo son venerados como dioses y la actitud escéptica se ha tomado como la única forma posible de pensamiento crítico. Sin embargo, el escepticismo no es más que una de las muestras más poderosas del pensamiento orgánico de las sociedades imperiales. En estas sociedades el culto al monetarismo y sus secuelas lleva al desprestigio de todo tipo de creencias e ideologías. Las poses escépticas pasan a ser consideradas por esta vía paradigmas intelectuales posmodernos. 
Pro et contra

Estos son, en muy gruesos y apresurados trazos, algunos de los momentos de la evolución del debate acerca del realismo y su alternativa. Como todos los debates orgánicos, éste responde más a las tendencias profundas de cada momento histórico y a sus necesidades que a las demandas concretas suscitadas por las obras literarias y artísticas trascendentales. Estos estados de opinión son siempre inestables, superficiales y, en último término, falsos. Bastaría contrastarlos con las grandes obras del siglo XIX -como las de Coleridge, Baudelaire o Dostoievski, incluso Galdós o Balzac- para ver qué insuficiente es la noción de realismo para dar cuenta de ellas. De hecho, pueden servir de modelos para lo que algunos entendemos por modernismo o, quizá con mayor precisión, por simbolismo. Trataré de explicar esto.

El concepto de realismo se acuñó en la crítica literaria y en la crítica del arte francesas de mediados del s. XIX. Suele mencionarse a este respecto un acontecimiento, la exposición del pintor Gustave Courbet en París en 1855, titulada: "Gustave Courbet, el realismo". El crítico de arte y amigo de Courbet Champfleury se convertiría en el teórico oficial del realismo al publicar en 1857 un libro titulado precisamente El realismo. El concepto es, pues, periodístico y la crítica periodística lo había tomado de la filosofía. Allí realismo significaba lo contrario del viejo idealismo. Y coexistiría con otros términos como criticismo y materialismo sin tener un sentido demasiado preciso. Se trataba de afirmar un pensamiento del mundo y para el mundo, que no excediera los límites humanos y terrenales. Y algo parecido ha querido significar realismo en los estudios literarios: una literatura que se limita al mundo de los vivos, actual, orientada hacia el presente. Esa orientación hacia el presente (más bien sería hacia el pasado reciente) ha ofrecido un producto: el historicismo, que identificamos un tanto alegremente con la literatura del s. XIX. En efecto, en esa literatura, sobre todo en la novela, podemos encontrar muestras del historicismo y del interés por la actualidad. Pero también se encuentran esas mismas muestras en la literatura de hoy. Pondré un único ejemplo. En los últimos años ha 
tenido gran éxito de público y de crítica una novela: Soldados de Salamina de Javier Cercas. Sólo en España se han publicado casi cuarenta ediciones. Y se ha traducido a varias lenguas. Se trata de una novela basada en un caso real de la Guerra Civil española: la milagrosa salvación del fusilamiento del escritor fascista Rafael Sánchez Mazas, ocurrida en algún lugar de la provincia de Gerona. Además del hecho real, aparecen en esta novela el hijo de Sánchez Mazas, el escritor Rafael Sánchez Ferlosio y Roberto Bolaño, entre otros personajes reales. La fórmula está hoy muy difundida: se trata de mezclar hechos y personajes extraídos de la realidad con otros hechos y personajes de invención. En el lenguaje corriente suele decirse: historia y ficción. Sirva este ejemplo -se podrían poner muchos otros, sobre todo, en la literatura norteamericana- para mostrar la pervivencia y la actualidad del realismo en el siglo XXI.

Pero lo que quiere decir esta pervivencia viene a ser dos cosas distintas. La primera consiste en dar cuenta del esfuerzo del autor por presentar la materia literaria como verosímil. Este es un ideal que proviene desde la Antigüedad y el Humanismo clásico. Consiguientemente con ese ideal y su realización en la literatura y el arte modernos, algunos pensadores han creído que el realismo suponía el fin del arte, un estadio último, pues no podía darse una meta más elevada que la de introducir la realidad en el arte y el arte en la realidad. La segunda faceta del realismo consiste en poner la imaginación en línea con la historia. De ahí la gran importancia que tienen ciertos ecos históricos en la literatura que llamamos realista. Esa aspiración a fundir historia e imaginación es la consecuencia de otra más profunda y quizás más interesante que consiste en fundir el pasado reciente con el presente. ${ }^{2}$ En otras palabras, puede decirse que uno de los objetivos de nuestro tiempo consiste en in-

\footnotetext{
${ }^{2}$ Hoy es frecuente un concepto débil de realismo que se conforma con contener la imaginación en la frontera de lo verosímil. En un libro reciente, J. C. Mainer alude a un realismo menor que no sería más que una retórica realista, a propósito de la obra de Álvaro Pombo (263). Estos conceptos ilustran la débil posición de la noción de realismo, que, por otra parte, nació ya débil.
} 
troducir el presente en la historia o, al contrario, historiar el presente, convertirnos en espectadores del presente, en una forma parecida a como la historia nos ha hecho espectadores del pasado. Sin duda estas actitudes han tenido y tienen un peso relevante en la imaginación creadora de nuestra época. Pero, quizás, sean insuficientes para explicarla.

\section{Concepto de simbolismo}

Volveremos de nuevo a la novela de Cercas para ilustrar esa insuficiencia. Incluso Soldados de Salamina se presta a una interpretación de signo muy distinto del realismo, una interpretación que podríamos llamar modernista. La tercera y última parte de esta novela se presenta como la investigación del periodista que busca al héroe, al soldado republicano que libró de la muerte a Sánchez Mazas. Esa investigación toma la forma de un viaje, al final del cual el investigador encuentra al héroe. Pero viene a resultar que el salvador no quiere ser héroe, no busca la fama sino el bien. El viaje, la búsqueda de valores, la revelación son elementos claves en el simbolismo, que es mi forma de entender el modernismo. ${ }^{3}$ Dicho esto, creo que ha llegado el momento de explicar qué entiendo por simbolismo. Para empezar he de decir que simbolismo ocupa para mí la misma posición que para un sector de críticos ocupa el término modernismo, el de la alternativa al realismo. Quiero, sin embargo, remarcar dos diferencias cruciales respecto a la posición mayoritaria. Para mí el simbolismo es la estética moderna. Domina el siglo XIX y el XX. Y quizá siga ejerciendo su hegemonía en el XXI. Es la estética

${ }^{3}$ La crítica también ha atribuido el viaje, la búsqueda de valores e, incluso, la revelación al realismo. Así Fredric Jameson ha planteado un realismo providencialista. Creo que esta posición revela el conformismo de la crítica con los conceptos que parecen gozar de consenso. Sin embargo, podría resultar más productivo preguntarse por los límites de ese consenso y por la lógica que hay detrás de las categorías establecidas. 
del retorno de la oralidad. El realismo, en cuanto historicismo, es sólo un aspecto que no es ni contradictorio con el simbolismo ni se puede situar al mismo nivel. Por eso, he citado autores del s. XIX que representan la cima del simbolismo. A la pregunta qué es el simbolismo responderé que es una estética que representa la convergencia de las estéticas premodernas (patéticas, didácticas, humorísticas) con lo que habitualmente suele llamarse pensamiento mítico, el folclore de las culturas tradicionales prehistóricas, las culturas de la oralidad.

Pero me gustaría mostrar de inmediato que esta no es una ocurrencia más a propósito de este controvertido tema. Voy a intentar demostrar que algunos pensadores del siglo XIX ya vieron de una forma muy nítida el perfil simbolista del arte de su tiempo. Al menos, creo poder mostrar que mi interpretación del simbolismo es una consecuencia de lo que en su día pensaron Victor Hugo, Baudelaire o Dostoievski, por nombrar sólo los casos más notorios y representativos.

Quizá el planteamiento más eficaz desde un punto de vista conceptual fuera el de Victor Hugo. En su prólogo a Cromwell abordó de forma directa este asunto que nos ocupa. Y tras una magistral exposición de filosofía de la historia literaria concluye acerca de la era moderna:

La musa moderna contemplará las cosas desde una perspectiva más elevada y más amplia [que la épica o premoderna]. Comprenderá que en la creación no todo es humanamente bello, que en ella lo feo existe al lado de lo bello, lo deforme cerca de lo gracioso, lo grotesco en el reverso de lo sublime, el mal con el bien, la sombra con la luz. Se preguntará si la razón estrecha y relativa del artista debe tener la primacía sobre la razón infinita, absoluta del Creador; si el hombre debe corregir a Dios; si la mutilación de la Naturaleza aumentará su belleza, [...] si, en fin, ser incompleto es el mejor medio de ser armonioso. [...] La poesía dará un paso formidable [...]. Hará lo mismo que la naturaleza, mezclará sus creaciones, pero sin confundirlas, lo grotesco con lo sublime, el 
cuerpo y el alma, la bestia y el espíritu; ya que el punto de partida de la religión es siempre el punto de partida de la poesía. Todo concuerda (37-8)

Esta concepción del arte moderno no ha sido superada casi dos siglos después. En su idea de la gran evolución de la historia literaria Hugo identifica cada una de las tres grandes etapas con un género: la etapa primitiva con la lírica (y nos da el ejemplo del Génesis, con lo que observamos que su idea de lírica no es la convencional); la etapa antigua la ilustra con la épica, que habría que entender como relato heroico; y la etapa moderna con el drama. "El drama pinta la vida" (48), nos dice. Y aún más: “el carácter del drama es lo real; lo real resulta de la combinación perfectamente natural de dos tipos, lo sublime y lo grotesco, que se cruzan en el drama como se cruzan en la vida y en la creación. Pues la poesía verdadera, la poesía completa se encuentra en la armonía de los contrarios" (52). No hay contradicción entre el realismo y la estética de la armonía de los contrarios. Pocas líneas antes, a propósito de la naturaleza misma nos dice que bien podría ser interpretada una simple puesta de sol como "un sombrío drama en el que luchan el día y la noche, la vida y la muerte" (49). No hay contradicción alguna entre pintar la vida y concebirla como un drama. Se me dirá que esto es el romanticismo. Pero fue Baudelaire quien explicó que el romanticismo no es más que un adelanto del simbolismo en sus Poemitas en prosa.

Y ya que nombro a Baudelaire habré de aprovechar la ocasión para señalar la burla que le mereció el concepto de realismo, burla adornada de cierta ira contra el principal valedor de este concepto, el crítico Champfleury. Dice de él, "como estudia con minuciosidad, cree aprehender una realidad exterior. Y de ahí deduce un método, el realismo (quiere imponer lo que cree que es su procedimiento)" (132). Ya antes había tachado el realismo de "injuria insoportable" y "palabra vaga y elástica" (El arte romántico). Para Baudelaire el concepto clave es la imaginación. "La imaginación es la reina de lo verdadero, y lo posible es una de las provincias de lo verdadero". Y añade: "la imaginación es una facultad casi divina que percibe en 
seguida, sin necesidad de métodos filosóficos, las íntimas y secretas relaciones de las cosas, las correspondencias y las analogías" (Curiosidades estéticas).

También Dostoievski vino en nuestra ayuda con la siguiente observación a propósito de la estética de la Leyenda del Gran Inquisidor de Iván Karamázov que era también la suya: "aquí lucha el diablo contra Dios y el escenario de la batalla es el corazón del hombre". Esta estética es "capaz de contemplar todas las contradicciones posibles y contemplar de un golpe dos abismos, el que está encima de nosotros, el abismo de los altos ideales, y el que está debajo de nosotros, el abismo de la más baja y hedionda degradación". Naturalmente, no todos los autores modernos son capaces de introducir todo esto en una novela, como hizo el autor de Los hermanos Karamázov. Incluso Galdós, que cultivó las mismas pautas simbólicas que el gran novelista ruso, nos legó un lema que bien podría ser el lema del simbolismo, aunque ha sido leído en clave realista: "Ars, natura, veritas."

Pero estas observaciones no cristalizaron en una teoría superior, una teoría de la armonía de los contrarios. La crítica siguió las sendas abiertas por realistas y parnasianos. El simbolismo fue considerado en su momento y sigue siendo considerado por la historia literaria como una moda, una moda literaria y, a lo sumo, artística. En tanto que moda se la considera un fenómeno cultural vinculado a ciertos actos sociales (manifiestos, reuniones o publicaciones) y a determinadas influencias ideológicas (en especial, la difusión de las ideas de Emanuel Swedenborg, autor del libro Del cielo y del infierno, traducido al francés en 1872), que había conseguido infiltrarse en el terreno artístico a través de iluministas literarios como Gérard de Nerval, Novalis, Blake y Emerson. ${ }^{4}$ Entre los actos sociales suele

${ }^{4}$ Emanuel Swedenborg, pensador y científico sueco dedicado a la especulación mitico-religiosa, fundó la iglesia de la Nueva Jerusalén. Vivió entre 1688 y 1772. Además de De et ieus mirabilius, et de inferno (1758), publicó libros como Arcana coelestia (1749-56), Vera cristiana religio (1771) y Doctrina vitae pro Nova Hierosolyma (1763). Concebía la Trinidad como una sola persona, en la que el Espíritu Santo 
destacarse el banquete presidido por Mallarmé en 1891 que sirvió para proclamar el triunfo del simbolismo sobre el parnasianismo.

Paralelamente los historiadores del arte suelen hablar de simbolismo como un estilo, también francés en su origen, propugnado por artistas como Gauguin, la escuela de Pont-Aven y el grupo de los Nabís. Este movimiento pictórico se opone al neoimpresionismo. Tanto el movimiento poético como el pictórico vienen a coincidir en el tiempo (aunque suele señalarse la prioridad de los escritores, pues se tiene por primer acontecimiento simbolista la publicación de Las flores del mal en 1857).

Esta concepción del simbolismo como moda creativa, ya sea literaria o pictórica, toma este fenómeno como un acontecimiento ligado a una actualidad, que puede limitarse al último tercio del siglo XIX francés, pero que ha sido extendido por otros hasta los románticos (Shelley, Novalis, Wordsworth o Coleridge, en poesía; Blake y Turner, en pintura) y al siglo XX en diversas manifestaciones. Aunque se han señalado rasgos comunes en ambos campos (el idealismo, sobre todo) no resulta fácil extraer una síntesis común cuando se pone el acento en la convergencia entre música y poesía, de una parte, y de idea e imagen, de otra. Uno de los problemas de la caracterización de estos movimientos es que se suele llevar el debate al terreno del material que utilizan, que en campos diversos de la actividad estética es, forzosamente, distinto.

Otro de los problemas que suscita el simbolismo es, como ya queda apuntado, el de los límites de este movimiento. La crítica, desde Edmund Wilson, ha tendido a ampliar los límites cronológicos, sobre todo en dirección al siglo XX. La limitación cronológica ini-

representa la vida y actividad de lo "humano divino". Toda creación y sabiduría tienen su origen en el amor y sabiduría divinos y, por tanto, se corresponden como materia y espíritu. Kant se tomó lo sufiencientemente en serio su pensamiento como para dedicarle su ensayo Los sueños de un visionario (1766). Balakian certifica la referencia común de todo el simbolismo a Swedenborg, "el cual había conseguido infiltrarse en el terreno artístico a través de iluministas literarios como Gérard de Nerval, Novalis, Blake y Emerson" (22). 
cial es el producto de una concepción periodística de un fenómeno estético. Esa concepción periodística está atenta a la actualidad. Ve un movimiento de reacción frente a un panorama hegemonizado por otra moda (el parnasianismo) y explica ese fenómeno en función de los datos externos visibles. Después los historiadores del arte y de la literatura se encargan de rellenar de contenido una percepción periodística. Tal punto de partida es necesariamente empobrecedor e insuficiente para comprender el fenómeno que intenta reflejar. Este método no puede dar cuenta ni de los orígenes ni de lo fundamental de este hecho y estará sometido a una vacilación permanente sobre sus límites. ${ }^{5}$

Los fenómenos estéticos - entendiendo como tales los movimientos que inciden en varias artes al mismo tiempo- suelen ser comprendidos como fenómenos culturales, definidos por un marco ideológico y una situación histórica precisa. Un estudioso brasileño, Álvaro Cardoso Gómes, explica el simbolismo como una reacción al pensamiento positivista y al ideal de progreso, que caracterizan el siglo XIX. Sin duda, estos factores influyeron en la expansión de

${ }^{5}$ Edmund Wilson abre su libro El Castillo de Axel con un capítulo sobre el simbolismo. En él afirma lo siguiente: "No suele reconocerse que escritores como W. B. Yeats, James Joyce, T. S. Eliot, Gertrude Stein, Marcel Proust y Paul Valéry representan la culminación de un movimiento literario consciente y muy importante; y aun si nos damos cuenta de que estos escritores tienen algo en común entre sí, de que pertenecen a una misma escuela, es probable que nos cueste determinar cuáles son sus rasgos distintivos" (11). Tengase en cuenta que semejante afirmación se publica en 1931. R. Wellek (1983) señaló tres concepciones históricas del simbolismo, que van desde la más restringida de apenas dos décadas de poesía francesa de fines del siglo XIX a otra de mayor alcance que llega hasta 1940 e incluye la obra de Valery. Recientemente Nil Santiáñez ha propuesto para la historia literaria española tres modernismos. El primero de corta duración: los últimos años del siglo XIX y la primera década del siglo XX, al que habría que añadir las novelas de la "gente vieja" (es decir, algunas novelas de Clarín, Galdós, Lanza y otros). El segundo modernismo, de media duración, abarcaría desde el último tercio del siglo XIX hasta la guerra civil de 1936. Un tercer modernismo de larga duración iría desde el Quijote y que alcanza de lleno al siglo XX (con Joyce, Döblin, Dos Passos, Faulkner, Proust y Martín Santos (Santiáñez, 132-35). El concepto de modernismo que defiende Santiáñez parece demasiado lato, pero se parece al de simbolismo. 
este movimiento, pero, en general, los grandes fenómenos estéticos suelen tener raíces mucho más profundas en el pasado y su relación con el momento en que florecen no es más que la culminación de un largo proceso de gestación para cuyo alumbramiento se dan las condiciones precisas. Sin embargo, la concepción históricoculturalista de la literatura y las artes suele dar lugar a un relato de segmentos discontinuos más parecidos a una sucesión de modas que a una cadena de fenómenos históricos sólidamente enraizados o engarzados.

Una muestra de la insuficiencia del modelo cultural nos la ofrece, en el caso del simbolismo, la influencia atribuida a las ideas de Swedenborg. Swedenborg fue un teólogo sueco del siglo XVIII. Es verdad que sus obras se tradujeron al francés en el siglo XIX, pero el modelo cultural no explica cómo pueden servir ideas viejas para iluminar una reacción contra el positivismo o contra el parnasianismo. ${ }^{6}$ Las posiciones que han tendido a primar el carácter idealista y antipositivista del simbolismo tienden a establecer una continuidad con el movimiento romántico. Los que priman la reacción parnasiana lo reducen a su dimensión poética. Y, en todos los casos, la reducción más importante es que se intenta explicar este fenómeno por una posición ideológica, que es como suelen explicarse los fenómenos culturales.

Nuestra propuesta para explicar el fenómeno simbolista sigue una orientación opuesta al método cultural. Frente a la tendencia a la explicación contemporánea del culturalismo nuestro método se apoya en la verticalidad de las grandes tendencias sociales, sobre todo las estéticas. En este sentido seguimos la principal enseñanza de Norbert Elias: la necesidad de estudiar los fenómenos humanos a una escala temporal muy grande. Esto nos permite llegar a la

${ }^{6}$ Estas concepciones del rechazo antimoderno deben ser tenidas en cuenta en su parte de verdad. En el siglo XX algunos estudiosos han visto en el simbolismo modernismo, superación del viejo realismo. Podría argumentarse que el antimodernismo originario termina siendo modernismo, pero la contradicción de esta lectura moderna del simbolismo es, a la luz del fenómeno, flagrante. 
siguiente conclusión. El simbolismo moderno representa la fusión de un simbolismo hermético, serio que tuvo un importante desarrollo en el humanismo con un simbolismo humorístico que funda las obras de Rabelais, Cervantes, Shakespeare y Goethe, entre otros.

Esta tesis fue avanzada parcialmente hace ya dos décadas por Rafael Gutiérrez Girardot. Digo parcialmente porque el pensador colombiano vio sólo la dimensión hermética, sin reparar en la humorística. Gutiérrez Girardot llamó la atención sobre el "aspecto religioso" del Modernismo, como fenómeno europeo y latinoamericano. Y destacó especialmente el fenómeno de la secularización, que es a la vez desacralización del lenguaje religioso y sacralización del mundo (1988, 50-1). ${ }^{7}$ En ese horizonte secularizador se forma la "lírica moderna". "El proceso de secularización se inicia con la Ilustración en el siglo XVIII, continúa a comienzos del siglo XIX con la Ideología de Destutt de Tracy y el utilitarismo de Jeremy Bentham y se extiende con el krausismo en España y el positivismo en Latinoamérica durante la segunda mitad del siglo XIX” (48). Según Gutiérrez Girardot, tras los pasos de Schlegel, Schelling, Hölderlin y Hegel, que plantean la necesidad de una nueva mitología para recuperar un supuesto paraíso perdido mediante una cultura secular, se produce "la apertura a un reino que daba sentido a la vida, o al menos lo prometía" que se legitima mediante una tradición que invoca "arcanas y arcaicas teorías":

desde Orfeo y los misterios de Eleusis, Odín, el corpus bermeticum de Bizancio, el neoplatonismo y neopitagorismo místico, pasando por Merlín, el Graal, el Ars magna de Lulio y

${ }^{7}$ La tesis de la raíz hermética del simbolismo ha tenido una larga y lenta gestación. Precursores de esta tesis son Bowra, que vio en el simbolismo la manifestación literaria de una experiencia sobrenatural y Wilson, que subrayó en El Castillo de Axel la dimensión críptica y de retirada al mundo interior de la torre de marfil de los autores simbolistas. También Balakian subraya los fundamentos místicos de la conexión swedenborgiana, presente ya en los románticos. Angelo P. Bertocci remonta los antecedentes del simbolismo hasta Plotino y considera a Baudelaire su culminación (Balakian 15). 
la alquimia en la Edad Media; por Marsilio Ficino, Cornelio Agripa, Paracelso y Nostradamus (el pertinaz best-seller) en el Renacimiento; por Jacob Böhme, las diversas masonerías, el iluminado Swedenborg, Cagliosto el aventurero, el pío Franz von Baader, los carbonarios, J. G. Hamann, "el mago del Norte" en los tiempos modernos, hasta los codificadores variados de estos saberes, como Eliphas Lévi, Allan Kardec, Helena-Petrovna Blavatsky, el franco-gallego, ingrato estudiante de medicina Gérard-Anaclet-Vincent Encausse [...] llamado Papus, y Joséphin Péladan, que se dio por nombre de batalla el de San Mérodak (según el rey de Babel, MerodacBaladán). (Gutiérrez Girardot 78-9)

Este conjunto que Gutiérrez Girardot denomina “corpus doctrinario" constituye el fundamento del simbolismo hermético. El simbolismo hermético ha alcanzado su mayor relieve en poesía. El simbolismo francés -Baudelaire, Verlaine, Rimbaud- es el gran referente, aunque tiene antecedentes (el romanticismo) y sucesores: Yeats, T. S. Eliot, Ezra Pound, Auden, en la literatura inglesa, Lorca, Neruda, Vallejo, Breton, Valery, Paul Celan, Montale, en otros dominios. Pero también existe un hermetismo en prosa que incluiría desde E. A. Poe, a J. L. Borges y Juan José Arreola, entre otros muchos. Las raíces de este hermetismo moderno se remontan al hermetismo humanista de los neoplatónicos y otros. Ese hermetismo humanista tiene sus orígenes en la asimilación que del pensamiento mítico y de la magia tradicional hizo la Antigüedad (en el Corpus Hermeticum y en los tratados de Estobeo y Asclepio).

Pero hay otro simbolismo cuya raíz es directamente tradicional y que proviene de la asimilación de géneros tradicionales (cuentos, leyendas, canciones, enigmas...) y, en general, de la cultura popular y folclórica. Ese simbolismo se ha expresado, en primer lugar, en la novela, aunque está presente en todos los demás géneros literarios y las otras artes. Ha desarrollado varias líneas: desde la aventura (Melville y la novelística infantil) al humorismo (Dostoievski, Kafka, Calvino, Cortázar), pasando por la llamada novela de la tierra o familiar (Cien años de soledad y Pedro Páramo) y la novela de aprendizaje. 
Para comprender la vinculación de la faz hermética de la musa moderna con el humorismo moderno es imprescindible recuperar las ideas de Victor Hugo y de Dostoievski, complementadas con reflexiones como las de Ortega. Esas ideas representan el camino para, tras depurar la perspectiva crítica de su servidumbre periodística, poder captar la profunda unidad de la estética moderna. Pero no será suficiente con una aproximación interna. Un fenómeno que afecta a toda una época, como es la Modernidad, tiene que tener sus correspondencias en otros fenómenos modernos. Con ellos debe formar un conjunto dotado de sentido dentro de la línea de la gran evolución social y cultural de Occidente. En concreto, en el ámbito de la cultura y de las humanidades un fenómeno parece atravesar este campo. Es el retorno de la cultura de la oralidad y de la imaginación tradicional.

\section{El retorno de la oralidad}

Este planteamiento transversal puede parecer sorprendente pero otros pensadores han llegado a esta o parecida conclusión, desde otros puntos de vista y persiguiendo objetivos muy distintos. El primero de estos pensadores fue Marshall McLuhan, uno de los grandes profetas de nuestro tiempo. McLuhan definió en primer lugar las leyes que gobiernan la cultura escrita, que él achacó a la invención de la imprenta (La Galaxia Gutemberg). Y, en un segundo momento, teorízó el regreso de la oralidad, que atribuyó a las nuevas tecnologías, desde el telégrafo a la telefonía y radiofonía. La consecuencia social del regreso de la oralidad sería la retribalización de la sociedad moderna y, en verdad, vemos que el fenómeno de las nuevas tribus recorre Europa y América, desde los sectores más populares a los más cultos y poderosos.

Otra línea de pensamiento, que ha venido a recalar a la misma cuestión, viene dada por los estudios del folclore. Desde comienzos del s. XIX Europa descubrió la literatura oral, la cultura popular, la Volkpsycologie. Desde los hermanos Grimm a Anti Aarne (el fundador del índice de tipos folclóricos) o Afanásiev, pasando por 
la obra de Wundt, Gunkel y Bultmann (estos en los estudios bíblicos), hasta Stith Thompson y centenares de eruditos, la investigación del folclore ha sido un fenómeno central para la cultura de la Modernidad. Esta orientación ha dado lugar a una nueva disciplina, la antropología, cuyo papel es cada día más relevante en el sistema de las disciplinas humanísticas.

Otro aspecto de este fenómeno revolucionario es el del relieve que ha adquirido la cuestión de la oralidad frente a la escritura y que ha alcanzado a varias disciplinas, desde la filosofía con Eric Havelock, a los estudios literarios (Bajtín, Zumthor), la psicología (Luria, Jung), la sociología de Norbert Elias y, por supuesto, la antropología. Esta dimensión interdisciplinar conlleva un replanteamiento de la jerarquía de las disciplinas actuales. Si con la irrupción de la Modernidad hacia 1800 las disciplinas humanísticas se agruparon en torno a la Historia, hoy una reestructuración de las disciplinas está en marcha. Es la revolución que podemos apreciar en los estudios culturales. Ese movimiento, sin embargo, tiene un carácter contradictorio: responde a la vez a la revolución de las disciplinas, que tiende a poner en el centro de las humanidades a la antropología (con un lugar preferente para la estética y la hermenéutica) y a la tendencia al eclecticismo que domina las sociedades imperiales. Pero ésta no es la cuestión que nos ha traído aquí y, por eso, volveremos de inmediato a nuestro tema.

\section{E1 simbolismo y sus formas}

No menos relevante que todas estas facetas es la dimensión estética del retorno de la oralidad y del simbolismo. El simbolismo es la estética del retorno de la oralidad. Podríamos matizar diciendo que no es un retorno simple a la oralidad primitiva. Se trata de un giro que debe recargar la cultura histórica, la cultura de la escritura, con el tesoro recuperado de la oralidad primitiva. ${ }^{8}$

\footnotetext{
${ }^{8}$ La presencia de la oralidad en la literatura moderna adopta formas variadas y,
} 
No pretendo exponer en el breve espacio de que dispongo un esquema completo de este problema. Me limitaré a señalar que el retorno de la oralidad y su contenido, el simbolismo, es el producto del proceder del pensamiento histórico (me refiero a la forma de pensar que caracteriza a las culturas históricas, las culturas de la escritura). Ese proceder se funda en mixtificaciones, esto es, en mezclas y confusiones (unas deliberadas y otras, no). Y esas mixtificaciones tienen sus momentos de revelación, sus big bangs, sus revoluciones. En mi opinión, ha habido dos de esos momentos -que tienen una cronología flexible, según las diversas culturas-. El primero es el de la irrupción de la historia, esto es, el de la formación de las sociedades abiertas, basadas en el monetarismo, en la escritura y en las disciplinas. El segundo es el de la aparición del individualismo, esto es, la era moderna. En el primero aparecen estéticas serias y estéticas humorísticas. En el segundo se produce una gran mixtificación estética, que combina las estéticas históricas con las tradicionales $\mathrm{o}$, dicho de otra forma, que tiñe las estéticas históricas de simbolismo tradicional, produciendo una forma de simbolismo nueva, demoníaca, moderna, a la vez dramática y cómica. Así lo comprendieron Victor Hugo, Dostoievski, Ortega y Cortázar, entre otros.

Esta lectura del simbolismo contrasta con la tendencia dominante respecto al concepto de Modernismo en el mundo anglosajón. Aunque no soy el primero en identificar simbolismo y modernismo (ya lo hizo Edmund Wilson en El castillo de Axel, una obra de 1969, como he señalado antes) sí pretendo darle a ese concepto un alcance superior que pueda servir de apoyo para una teoría de la Modernidad más ambiciosa, que forme parte de una filosofía de la historia literaria. También sería de desear que el debate pasara de ser una cuestión terminológica a una cuestión historico-filosófica.

en apariencia muy distantes. Esas formas van desde la función mítica o epifanía a la presencia del lenguaje de la calle, la oralidad del presente, en la poesía conversacional o en la novela y el cuento que ofrecen perspectivas analíticas del lenguaje común. 
Los conceptos del modernismo convencionales a los que trato de confrontar esta propuesta ponen de manifiesto la limitación más frecuente de la teoría sobre la literatura y la cultura: la ausencia de una perspectiva de la gran evolución, esto es, de una filosofía de la historia literaria que conciba su objeto como un todo. Estas actitudes parecen creer que la historia literaria es un discurso que se puede construir a pedazos. El siglo XX es un pedazo, un dominio manejable que se puede autonomizar de otros dominios, como el s. XIX, que vienen a entorpecer su lectura. Esta actitud reductora y productora de segmentos manejables va acompañada del olvido de la reflexión en otras disciplinas humanísticas. Sólo suele atender al horizonte de la historia literaria inmediata, en una suerte de formalismo. De hecho, como ha señalado Ródenas, los críticos que abanderan el Modernismo lo entienden como una ruptura entre el arte y la realidad, producto bien del desorden de la realidad (Eliot) o bien del desorden del arte (Lukács, Ortega, Trillling, Bell) (72). En mi opinión esa ruptura entre arte y realidad no existe porque no ha existido nunca la unión entre ambas. $\mathrm{O}$, mejor dicho, el arte y la realidad han tenido sus nexos de unión y una cierta contención del primero respecto a la realidad, variable según las épocas y los géneros. La mejor fórmula para dar cuenta de la relación entre la dimensión estética y la dimensión fáctica, lo real, es la de autonomía relativa. Nunca ha habido una ruptura ni tampoco una identificación. Ambas dimensiones caminan de la mano, pero siguen leyes y lógicas distintas y propias. Las falacias, como la del realismo, lejos de ayudar a comprender el problema lo dificultan.

\section{Referencias bibliográficas}

Baudelaire, Charles. Crítica literaria. Ed. Lydia Vázquez. Madrid: Visor, 1999.

Balakian, Anna. El movimiento simbolista. Juicio crítico. Madrid: Guadarrama, 1969.

Cardoso Gomes, Álvaro. A Estética Simbolista. Textos doutrinários comentados. São Paulo: Atlas, 1994. 
Gutiérrez Girardot, Rafael. Modernismo. Supuestos históricos y culturales. 2 ed. México: FCE, 1988.

Hugo, Victor. "Prólogo a Cromwelp". Manifiesto romántico. Escritos de batalla. Tr. Jaume Melendres. Barcelona: Península, 2001.

Jameson, Fredric. El realismo y la novela providencial. Tr. Marta Caro. Madrid: Círculo de Bellas Artes, 2006.

Meletinski, Eleazar. El mito. Literatura y folclore. Tr. Pedro López Barja de Quiroga. Madrid: Akal, 2001.

Mainer, José Carlos. Tramas, libros, nombres. Para entender la literatura española, 1944-2000. Barcelona: Anagrama, 2005.

Ortega y Gasset, José. "La agonía de la novela." Meditaciones sobre la literatura y el arte (La manera española de ver las cosas). Ed. E. Inman Fox. Madrid: Castalia, 1988.

Ródenas de Moya, Domingo. Los espejos del novelista. Modernismo y autorreferencia en la novela vanguardista española. Barcelona: Península, 1998.

Santiáñez, Nil. Investigaciones literarias. Modernidad, historia de la literatura y modernismos. Barcelona: Crítica, 2002.

White, Hayden. "La historia literaria de Auerbach: causalidad figurale historicismo modernista." Teorías de la historia literaria. Ed. L. Beltrán Almería y J. A. Escrig. Madrid: Arco-Libros, 2005. 301-324.

Wilson, Edmund. El castillo de Axel. Estudios sobre literatura imaginativa 1870-1930. Tr. Luis Maristany. Madrid: CUPSA, 1977. 